Int. J. Agril. Res. Innov. Tech. 10(2): 116-127, December 2020 Available online at https://ijarit.webs.com DOI: https://doi.org/10.3329/ijarit.v10i2.51585

https://www.banglajol.info/index.php/IJARIT

\title{
Place-based perceptions, resilience and adaptation to climate change by smallholder farmers in rural South Africa
}

\author{
W.A. Tesfuhuney* and E.H. Mbeletshie \\ Received 26 September 2020, Revised 18 December 2020, Accepted 24 December 2020, Published online 31 December 2020
}

\section{A B S T R A C T}

Unprecedented global climate change caused by human actions is becoming a challenge to agricultural systems' ability to meet and sustain production demands for food and raw materials for the increasing world population. Climate change has not spared the district, resulting in extreme weather events such as droughts, erratic rainfalls and increasing frosty winter days within the district. Smallholder agriculture in Sub-Saharan Africa is mainly dependent on rainfed agriculture, which has increased production uncertainty due to the increasing variability of climate. This study assesses the management of adaptation and resilience strategies by smallholder farmers in Joe Gqabi District Municipality in Eastern Cape, South Africa. The study revealed a significant response to climate variability by smallholder farmers, which involved the adoption of numerous adaptation and resilience strategies. The choice of resilience and adaptation strategies among community members is influenced by a diversity of factors amongst which are; household demographic characteristics, access to information and technology, household assets endowment and farmers' perception of climate change. Results from the study also reveal a lack of public and private institutional support to the farmers hence the lack of in-depth awareness of climate change by these farmers. Drawing on the results and conclusions, the study recommends strengthening the capacity of farmers and institutions for identifying and assessing climate change. There is an urgent need for proactive management of climate change through sustaining those attributes that are important for production (resilience) and developing new socio-ecological configurations that function effectively under new conditions (adaptation). Implementation of policy interventions that build on farmers' existing knowledge is also critical.

Keywords: Smallholders, Farmers' perception, Adaptation, Resilience, Climate change.

Department Soil, Crop and Climate Sciences, University of the Free State, 205, Nelson Mandela Drive, West Park, 9301, Bloemfontein, South Africa.

*Corresponding author's email: TesfuhuneyW@ufs.ac.za (Weldemichael A. Tesfuhuney)

Cite this article as: Tesfuhuney, W.A. and Mbeletshie. E.H. 2020. Place-based perceptions, resilience and adaptation to climate change by smallholder farmers in rural South Africa. Int. J. Agril. Res. Innov. Tech. 10(2): 116-127. https://doi.org/10.3329/ijarit.v10i2.51585

\section{Introduction}

Society, in general, has accepted climate change as a major global challenge affecting the entire world, currently and for an unpredictable future. Thompson et al. (2015) assets that climate change has and will for an unforeseeable future cause environmental perturbations that exacerbate the vulnerabilities of African agricultural systems. The United Nations, Department of Economic and Social Affairs, Population Division, UNEP (2015) predicts that some of the environmental changes will occur earlier in some regions than in other regions of the world. The African continent is under high pressure from climatic stresses because most regions have climates that are among the most variable in the world (Seneviratne et al., 2012). Africa's climate is driven by a complex of maritime and terrestrial interactions as well as the geographical characteristics of the regions (Boko et al., 2007). In South Africa, climate change has become a key concern. Ziervogel et al. (2014) state that the 2013 South African Long Term Adaptation Scenarios and the Fifth Assessment Report of the Intergovernmental Panel on Climate Change (IPCC AR5) for Representative Concentration Pathway (RCP) 8.5 predicts that warming in the interior will increase by $3-6^{\circ} \mathrm{C}$ by $2081-2100$ relative to the period of 1986-2005 while precipitation patterns are less certain. 
It is generally acknowledged that farmers' perception is increased their awareness of climate change and adapting to it. It has been documented that the success of adaptation measures is dependent on the farmers' perceptions of climate change (Okonya et al., 2013, Simelton et al., 2013, Moyo et al., 2012, Gbetibouo, 2009; Maddison, 2006). Farmers' perception of climate change refers to an aggregated awareness of the trend in the climatic parameters such as rainfall, temperature, drought and onset and end of the rainy season. According to Deressa et al. (2011), socioeconomic and environmental factors that include education, household size, livestock ownership, agro-ecological zone, farm size and access to credit, influence how farmers perceive and adapt to climate change. In South Africa, a case study of the Limpopo Basin revealed that about 95\% of interviewed farmers perceived long-term changes in temperature (Gbetibouo, 2009). According to Gandure et al. (2011), farmers in Gladstone, a rural village near Thaba Nchu in the Free State Province, perceive and adapt to long-term changes in climate. Farmers' perceptions of climate change and variability that are informed by local knowledge help advance understanding of climate change and its importance on agricultural land-use systems (Amadou et al., 2015).

Due to reliance on rainfed farming in Africa, climate change increases the vulnerabilities of food production systems with strong regional variability in the degree of losses in yields (Lobell et al., 2011; Berg et al., 2013; IPCC, 2014). Despite their economic and social status, it is imperative that smallholder farmers with limited resources adapt to these changes to sustain their livelihoods in the long run. Adaptation is a way for people to build future resilience and they do this by adopting appropriate technology using local knowledge (United Nations Framework for the Convention of Climate Change (UNFCCC, 2007). Although farmers have adapted and shown resilience to natural climate changes, there is a growing fear that farmers may not be able to display the same level of adaptation and resilience to current and future anthropogenic climate changes (Burton and Lim, 2005). Analysing adaptation strategies leading to resilience, therefore, can help in finding ways of helping smallholder farmers cope with the everincreasing changes in climatic conditions in Africa and the whole world.

According to Ifejika (2010), resilience is the ability of a system to deal with stresses and disturbances while retaining the same basic structure and ways of functioning, capacity for self-organization and capacity to learn and adapt to change. Resilience can be achieved by reducing vulnerability and increasing adaptive capacity. Three ways of building resilience have been identified by Food and Agriculture Organization/ Organization for Economic Co-operation and Development (FAO/OECD) (2012) and these include reducing exposure to non-climatic onfarm shocks, reducing the sensitivity of the system to shocks like drought by using droughtresistant varieties and increasing adaptive capacity.

Several climate change adaptation and resilience studies in South Africa have been conducted at the national level, however, it is important to focus at the local and household level. Therefore, the study was set to answer the question, how do smallholder farmers cope and adapt to the effect of changing in a climate so that they can be resilient to future threats of climate change? The purpose of this study is to increase the knowledge of adaptation and resilience with a focus on smallholder farmers' perceptions of the effect of climate change on agricultural crop and livestock production. Therefore, attempts were made to assess smallholder farmers' ability to employ adaptive management and resilience strategies to climate change and to evaluate the main factors that affect the implementation of adaptation and resilience strategies to improve the livelihood of smallholder farmers. The point of departure in the current research from the other farmer adaptation studies is that it builds on the existing body of strategies employed by farmers while drawing parallels and linkages between adaptation and resilience based on local perceptions.

\section{Methodology}

\section{Study area}

The study was conducted in the Joe Gqabi District in the Eastern Cape Province of South Africa. Joe Gqabi district is located on the northern border of the province with Free State and Lesotho. The district comprises of four local municipalities, the Elundini, Gariep, Maletswai and Senqu (Fig. 1). It is the smallest of the seven districts in the province covering 25,663 $\mathrm{km}^{2}$ (StatSA, 2011). As of the 2011 census, the district had a total population of 349768 , having a very low population density of 13 people per square kilometer. Most of the population is concentrated in the ex-Transkei areas of Mount Fletcher and Sterkspruit. The majority of the population is black Africans who are about $93.8 \%$ of the total population. Native Afrikaans speakers make up about 5.9\%; whites are $2.4 \%$ while native English speakers are about $1.6 \%$ of the total population (StatSA, 2011). Languages spoken in the district include isiXhosa with a majority of $70.5 \%$, Sotho at 20.2\%, Afrikaans at 5.9\% and English at 3.4\%. 
According to the JGDM (2015) report on longterm climate data analysis, the Joe Gqabi district is well known for its temperature fluctuations, with temperatures ranging between $42^{\circ} \mathrm{C}$ and $11^{\circ} \mathrm{C}$. It is also affected by unseasonal frost and cold that has a negative impact on agriculture. The long-term average maximum temperatures for Joe Gqabi District are mostly between $29^{\circ} \mathrm{C}$ and $30^{\circ} \mathrm{C}$ for January (Fig. 1). The area is only suitable for less sensitive crops due to this harsh climate. Elundini is lower in altitude and experiences warmer winters and this enables part of the District to be more suitable for cultivation (JGDM, 2015). The district can be divided into four rainfall zones. Some of the higher mountain peaks have between $800 \mathrm{~mm}$ and $1200 \mathrm{~mm}$ of rainfall a year. The eastern part of the District has between $600 \mathrm{~mm}$ and $800 \mathrm{~mm}$ a year; the central area has between $400 \mathrm{~mm}$ and $500 \mathrm{~mm}$; and the western area (Venterstad, Steynsburg and most of Burgersdorp) has less than $500 \mathrm{~mm}$ a year (JGDM, 2015).

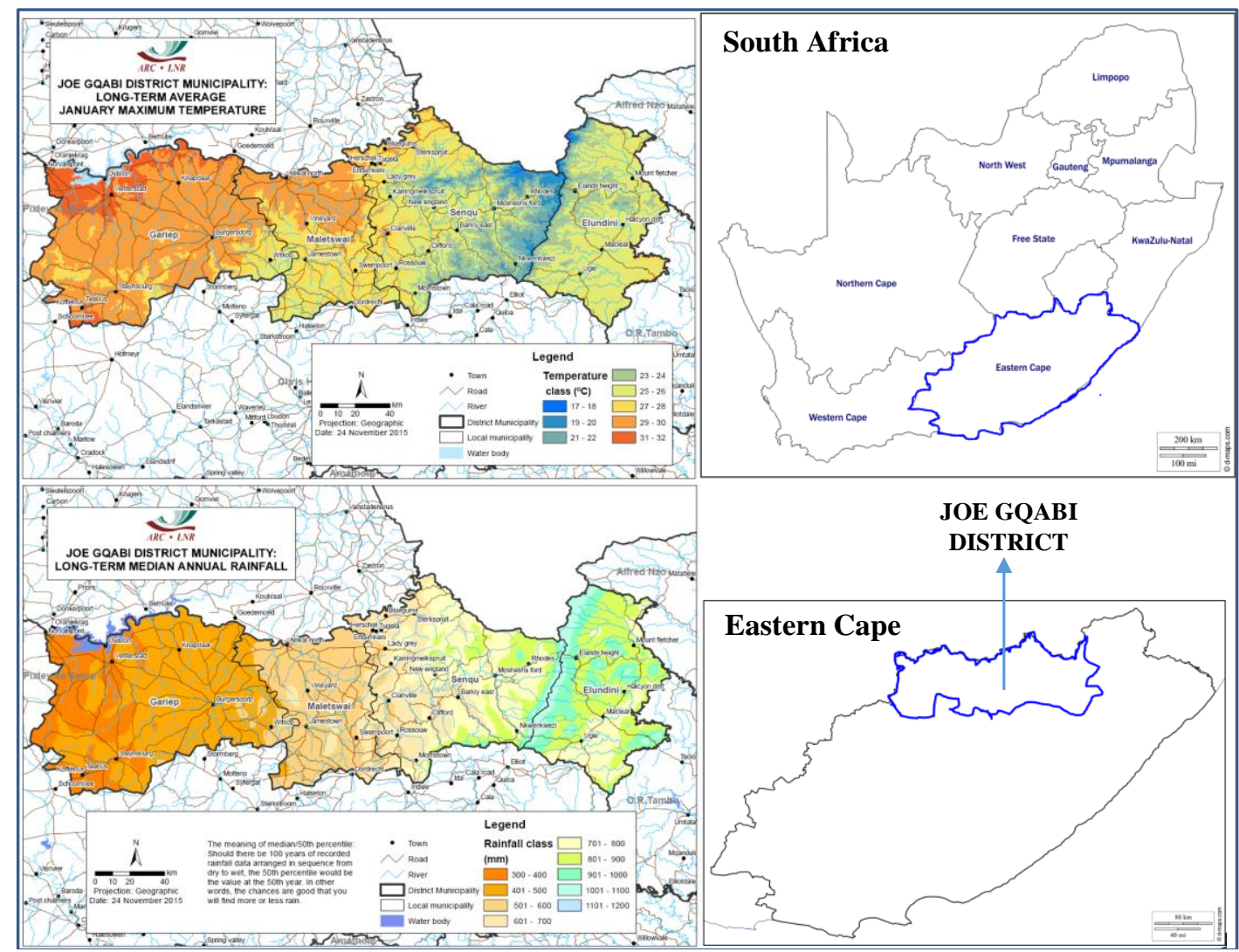

Fig. 1. Map of the study area (Joe Gqabi District) in Eastern Cape, South Africa (right) and ARC-LAN Maps indicate Average long-term January Tmax (left-top) and long-term median annual rainfall (left bottom).

Its topography is made of the dry Karoo flatlands and dry Namakaroo biomes to the west (Gariep and Maletswai). The east (Senqu and Elundini) is mountainous and wetter with some elements of the Maloti biome. The vast majority of the district falls within the Orange River catchment basin except for Elundini, which falls under the Mzimuubu river basin (ECSECC, 2014). The Orange River is the most important source of water in the district. The Gariep Dam is the largest in South Africa and, together with the Fish River Scheme, is the major source of water for irrigation. Many places in Senqu and Elundini have a high groundwater development potential. Nevertheless, it is hard to access by smallholder farmers vulnerable to the effect of climate change.
Joe Gqabi district is predominantly rural with the wetter mountainous eastern part (Elundini and Senqu) having communal land as well as commercial farming. The western municipalities of the district (Gariep and Maletswai) have flat Karoo vegetation and are dominated by extensive cattle and sheep commercial farming. Rainfed crop production dominates the ex-Transkei areas on the foothills of the Drakensberg Mountains while irrigation of maize and wheat takes place along the Orange River. Subsistence and emerging farmers are practicing conventional farming systems in the communal land areas. (DLGTA, 2011). 
According to the DLGTA (2011), there are only 233 hectares of high potential arable land in Joe Gqabi District. Compounded by limited rainfed arable land for crop production while irrigation schemes and stock farming play a significant role in agriculture. Intensive farming is only implemented in areas where water and agricultural infrastructure are available. The limited land, which can sustain intensive farming, and land which has been identified as having a high agricultural potential, has been reserved for farming to enhance food security and therefore economic welfare in the district. There is little agricultural processing in the district (DLGTA, 2011). It is against this background that farmers' perceptions, adaptation and resilience are examined in the district.

\section{Research design and data collection}

The research was designed in the form of a case study. This approach was employed to carry out a detailed analysis of farmers' perception to climate, how they adapt and build resilience to changing in climate and variability. According to Yin (2003), a case study constitutes an empirical inquiry that investigates a contemporary phenomenon within a real-life context and showed the benefit of the tool in answering the 'how' and 'why' questions. A quantitative research methodology formed the basis of the study although a qualitative nature was partly employed. The quantitative approach enables the researcher to identify statistical relationships between variables using data from structured and validated data collection instruments. Normally results from quantitative research can be easily generalized to other populations. In the case of the qualitative approaches, various data can be collected through probing and follow-up questions.

Data collection was carried out with technical support from Imbumba Beef Production Primary Cooperative (IBPPC), a Non-Governmental Organization (NGO) based in Ladys Grey involved in providing extension services to communal farmers. Enumerators were sought from Tsolo Agriculture and Rural Development Institute students who were attached to IBPPC and were familiar with the local communal farmers. The data collected by enumerators was checked and verified and all clarifications were dealt with during the survey at the study sites.

The research employed both a quantitative approach and some qualitative elements for additional clarifications. Specific research methods that were employed included a household survey, interviews and secondary data review and analysis. The survey collected both qualitative and quantitative data on demographic, economic aspects of households, agricultural activities and farmers' perception of climate change, and how farmers adapt and build resilience to climate change. A questionnaire was used to extract data from the 90 sampled farmers. Qualitative data were collected through Participatory Rural Appraisal (PRA) techniques. The researcher was involved in key informant interviews (KII) with leaders of IBPPC and local agricultural experts to get information on their knowledge and experiences. Secondary data collected from different sources was important in building the background information of the study.

\section{Analysis}

Data collected through the questionnaire was post-coded and captured using the Excel spreadsheet. The data were analyzed through descriptive statistics, tables and crosstabs. Data from Excel was then exported to Statistical Package for Social Sciences (SPSS) to carry out a regression using the Logistic Regression Model (LRM). The LRM method was used to analyze the main factors that affect the implementation of adaptation and resilience strategies by smallholder farmers in JGDM. Based on the information gathered through the survey, therefore, themes were identified as the main factors influencing the adoption strategies. These themes are demographic factors, farmers' perceptions, access to information and technology, assets and resources and farm activities. Logistic regression was then used to analyze how these factors influence the adoption of each strategy. The most dominant strategies identified by farmers were selected for this analysis. The general model of the logistic regression is given by:

$$
Y=\beta_{o}+\beta x_{1}+\beta x_{2}+\ldots+\beta x_{n}
$$

Where, $Y$ is the adaptation/resilience strategy, $\beta_{o}$ is an intercept and $x_{1}, x_{2} \ldots x_{n}$ are variables that influence resilience and adaptation strategies

Data collected through qualitative methods were analyzed in a thematic approach. The thematic approach entailed coding this data according to the themes that had been developed for the study based on the objectives of the study. Data on farmer perception was categorized into causes and perceptions of climate change. The climate change impact assessment on farmers' livelihood were divided into positive/negative and further subdivided into categories of impact on crop production, water availability for livestock and socio-economic status. Information from the statistical and thematic analysis was used to form the results for the study. 


\section{Results and Discussion}

\section{Perceptions on changes in weather patterns}

Data from the survey indicate that all interviewed farmers were aware of temperature changes in the region within the last 5 years. However, not all the farmers agreed as to the direction the temperatures were going. The majority of respondents (69\%) perceive temperatures to have cooled down than warming up. This perception by farmers is corroborated by the Joe Gqabi District Municipality (JGDM) (2015), which states that on average there are 150 days of frost and snow during the year between March and November in the Senqu and Elundini local municipalities. Snowfall has also been witnessed in higher-lying municipalities of Maletswai and Gariep in recent years. Results on precipitation indicate that again all the respondents perceive a change in rainfall patterns in the last 5 years. A greater percentage (86\%) perceives that the district is becoming drier than it was 5 years ago. These perceptions seem to be supported by the observed shifts from cereal production to animal husbandry and drought-tolerant crops. Overall, $100 \%$ of the respondents feel that the weather, in general, is changing with $91 \%$ attributing these changes to climate change. Farmers' awareness of these global environmental events can be attributed to the high literacy levels of farmers in the district together with access to media.

\section{Perceptions on the causes of weather variability}

Part of the survey was to ask farmers to identify extreme weather events that had affected the region since 2005. Results in Table 1, show that all respondents said they had witnessed drought events in their district with an average of 3.2 events affecting the area. High temperatures and late rainfalls were the other events identified by $83 \%$ and $82 \%$ of the farmers, respectively. These two events can be associated with the occurrence of long dry-spell during the rainy season and lead to medium to severe drought events. The frequency of high temperatures and late rainfalls since 2005 is 3.0 and 2.4, respectively, frequencies that are very close to that of droughts for the same period. Snowfall has been observed by $77 \%$ of the respondents with an average frequency of 2.9. Inconsistent rainfall and rainfall ending earlier than normal were observed by $74 \%$ and $60 \%$ for the respondents, respectively. Generally, a number of extreme weather events have been witnessed within the district, which can be a sign of increasing weather variability associated with climate change.

Table 1. Extreme weather events affected the region and perceived causes of extremes from 2005.

\begin{tabular}{|l|c|c|}
\hline Weather Event & Farmers observed (\%) & Frequency \\
\hline Droughts & $20 \%$ & 3.5 \\
\hline Increasing flooding & $100 \%$ & 3.2 \\
\hline Late rainfall seasons & $37 \%$ & 1.9 \\
\hline Rainfall season ends early & $82 \%$ & 2.9 \\
\hline Rains came earlier than normal & $60 \%$ & 2.4 \\
\hline Rains not consistent during the season & $32 \%$ & 2.2 \\
\hline High temperatures & $74 \%$ & 3.5 \\
\hline Snowfall & $83 \%$ & 3 \\
\hline Low temperature & $77 \%$ & 2.9 \\
\hline b) Perceived causes of extreme events & $20 \%$ & 4.8 \\
\hline Weather conditions & & 3.2 \\
\hline Rainfall decrease & $7 \%$ & 3.8 \\
\hline Temperature fluctuation & $4 \%$ & 2.8 \\
\hline Heat waves & $7 \%$ & 2.4 \\
\hline Global warming & $11 \%$ & 1.9 \\
\hline GHG emission & $2 \%$ & 2.1 \\
\hline El Nino effect & $9 \%$ & 4.5 \\
\hline Climate change & $4 \%$ & 5.2 \\
\hline
\end{tabular}

Farmers were further asked to identify what they perceived as the causes of these weather events they had observed in their region. Their numerous responses were categorized into a few themes for easy analysis and the results are presented in (Table 1). The majority of farmers attributed the occurrence of these events to climate change, although the other themes had low responses, these themes cannot be completely dissociated with climate change. The results indicate an increasing awareness of climate change by smallholders and how it is affecting the livelihood. To some extent, it was also difficult to differentiate with the real meaning of extreme events for rural communities but paves a road to open further discussions with the effect on their daily activities. 
Farmers' perceptions of climate change effect on Agriculture

For farmers to identify appropriate strategies to mitigate the effects of climate change, they need to know the effects and extent of damage posed by weather variability. These effects are in the form of yield loss, livestock death, pest and diseases, etc. The results in Table 2 present the findings from the survey concerning farmers' perceptions of the effects of climate change. An above-average of respondents indicated that the occurrence of extreme weather events has effects on agricultural production. Above $50 \%$ of the farmers indicated that agriculture was being affected a lot in terms of yield loss, animal death, reduced quality of produce, disease prevalence and frequency of pest outbreaks. A proportion of $51 \%$ of the farmers in the district perceives climate change as a purely natural phenomenon (Table 2). These natural causes include natural changes in winters, low/high temperatures, changes in precipitation and changes in wind movement, among others. There is a greater tendency to disregard human influences as indicated only by a meager $17 \%$ of the respondents. From the respondents, 25\% attributed global warming to increasing climate variability, a response that can be linked to a lack of understanding of the connections between anthropogenic effects and global warming. Although the farmers in the district are aware or have heard about climate change, the results reveal a need to increase this awareness on the linkages between human activities, greenhouse gases and global warming leading to climate change. Farmers were also asked to highlight the environmental impacts of climate change, especially on their livelihoods. Results in Table 2 show that about $40 \%$ of the farmers believe climate change is causing a decline in on-farm production. About $20 \%$ of the farmers indicated that it was affecting the quality of their crop and livestock production. Land degradation and increasing costs of production were mentioned by $15 \%$ of the respondents. A smaller proportion, less than $10 \%$, of the farmers mentioned the death of livestock and an increase in pests and diseases as some of the effects of climate change.

Table 2. Effects of climate change on agricultural production and perception on causes of change.

\begin{tabular}{|c|c|c|c|c|c|}
\hline \multirow[t]{2}{*}{ a) Effect on Agricultural Production } & \multicolumn{5}{|c|}{ Respondents (\%) } \\
\hline & Not at all & Little & Average & A lot & All \\
\hline Yield loss /Animal death & $0 \%$ & $2 \%$ & $34 \%$ & $60 \%$ & $3 \%$ \\
\hline Reduced quality & $0 \%$ & $19 \%$ & $24 \%$ & $53 \%$ & $3 \%$ \\
\hline More diseases & $12 \%$ & $8 \%$ & $23 \%$ & $53 \%$ & $3 \%$ \\
\hline More pests & $14 \%$ & $18 \%$ & $13 \%$ & $54 \%$ & $0 \%$ \\
\hline b) Perception on the causes type & Natural & Human & Weather & Global & All \\
\hline & $51 \%$ & $17 \%$ & $7 \%$ & $25 \%$ & $0 \%$ \\
\hline c) Perception on effect to environment & $\begin{array}{c}\text { Land } \\
\text { Degradation }\end{array}$ & $\begin{array}{c}\text { Prod. } \\
\text { Decline* }\end{array}$ & $\begin{array}{c}\text { Pest } \\
\text { disease }\end{array}$ & $\begin{array}{l}\text { Quality } \\
\text { produce }\end{array}$ & $\begin{array}{l}\text { High } \\
\text { cost }\end{array}$ \\
\hline & $15 \%$ & $43 \%$ & $7 \%$ & $20 \%$ & $15 \%$ \\
\hline
\end{tabular}

*Represent for both crop production decline (40\%) and animal death (93\%).

\section{Assistance given to the farmers}

In this study, the unavailability of NGOs and other private companies working in the rural communities indicated the limited assistance has reached in the district (Table 3). A range of 60\% $68 \%$ of the respondents indicated that no services like surveys, studies, adaptation, pilot projects and extension, among others, had been offered to the communities in the study area. Due to the existence of IBPPC, which works with a few selected cattle farmers in the district and average of $3 \%$ of the farmers, had received a lot of assistance from outside. On further probing, most farmers indicated that they would appreciate assistance in terms of training and information on climate change, capital to restructure their farms, help to access modern technology, help to maintain their farm equipment and above all more land to expand their activities.

Table 3. Level of assistance given to rural communities in Joe Gqabi District.

\begin{tabular}{|l|c|c|c|c|c|}
\hline Action Taken & Non & Few & Average & Many & A lot \\
\hline Surveys & $64 \%$ & $29 \%$ & $3 \%$ & $0 \%$ & $3 \%$ \\
\hline Climate and meteorology studies & $68 \%$ & $29 \%$ & $0 \%$ & $0 \%$ & $3 \%$ \\
\hline Awareness and training events & $60 \%$ & $10 \%$ & $19 \%$ & $3 \%$ & $8 \%$ \\
\hline Adaptation pilot project & $66 \%$ & $20 \%$ & $11 \%$ & $0 \%$ & $3 \%$ \\
\hline Widespread adaptation efforts & $68 \%$ & $19 \%$ & $10 \%$ & $0 \%$ & $3 \%$ \\
\hline Information about adaptation methods & $64 \%$ & $8 \%$ & $21 \%$ & $3 \%$ & $3 \%$ \\
\hline Extension training and services & $61 \%$ & $13 \%$ & $19 \%$ & $3 \%$ & $3 \%$ \\
\hline
\end{tabular}




\section{Farm adaptation strategies}

Changing the planting schedule and camp rotation are the most dominant adaptation strategies employed by farmers in the district (Table 4). Another strategy mostly used by farmers engaged in animal husbandry is changing mating, calving and weaning dates (97\%). The strategy ensures that these production systems in animal breeding coincide with seasons of adequate water and pastures. The provision of adequate food and water at these critical stages reduces loss due to animal starvation and death. Changing crop type and increasing small livestock holding while reducing large livestock are strategies employed by $92 \%$ and $82 \%$ of the farmers, respectively. These adaptation strategies are adopted to counter the frequent droughts and long dry spells as they enable farmers to divert to farm productions that are drought tolerant. Farmers also use a flexible cropping schedule for a good and bad season as an adaptation strategy. To counter the effects of water shortage in the district, about $43 \%$ of the farmers have sunk boreholes and installed windmills while $77 \%$ have increased their water reservoir capacity to ensure a continuous supply of water during the dry seasons. An above-average number of farmers have switched to planting fodder crops to feed their animals during the dry season when pastures are poor. This is also complemented by $49 \%$ of the farmers who have installed feedlots in their paddocks to supply supplementary feed during the dry spells. Considering the decrease in crop production in favour of animal husbandry, a meagre $32 \%$ of the farmers practice zero tillage as a method of conservation farming. The shift from crop to livestock production is supported by $40 \%$ of the farmers who have adopted the strategy to switch-on to animal husbandry.

Table 4. Percentage of farmers Adaptation strategies adopted by smallholder farmers in JGDM (a) and resilience strategies adopted by farmers in crop farming (b) and animal husbandry (c).

\begin{tabular}{|c|c|c|c|c|c|}
\hline \multirow{2}{*}{$\begin{array}{l}\text { a) Adaptation strategies } \\
\text { employed by farmers }\end{array}$} & \multirow[t]{2}{*}{$\%$} & \multicolumn{4}{|c|}{ Resilience strategy } \\
\hline & & a) Crop production & $\%$ & b) Animal husbandry & $\%$ \\
\hline Borehole/windmill & 43 & Irrigation Frequency & 15 & Buying livestock feed & 56 \\
\hline Shifting crop -livestock & 40 & Replanting & 86 & Storing feed / residue & 44 \\
\hline Planting fodder & 60 & Improve drainage & 24 & Camp rotation & 100 \\
\hline $\begin{array}{l}\text { Changing mating/calving/ } \\
\text { weaning }\end{array}$ & 97 & Delay planting & 61 & $\begin{array}{l}\text { Supplying high energy } \\
\text { licks }\end{array}$ & 78 \\
\hline $\begin{array}{l}\text { Changing planting } \\
\text { schedule / dates }\end{array}$ & 100 & $\begin{array}{l}\text { Short maturing cultivar } \\
\text { / variety }\end{array}$ & 96 & $\begin{array}{l}\text { Keeping calves/ lambs } \\
\text { on feedlot }\end{array}$ & 60 \\
\hline Changing suitable crops & 92 & Drought tolerant & 92 & Installing water tanks & 65 \\
\hline Increase ruminant number & 82 & Mixed cropping & 83 & Reducing livestock & 24 \\
\hline Camp rotation & 100 & Planting directly & 60 & Building animal shelter & 100 \\
\hline Increase feedlot & 49 & fodder & 72 & Inoculating/vacc & 57 \\
\hline Zero tillage practices & 32 & Water harvesting & 81 & Culling large ani & 36 \\
\hline Increase water reservoirs & 77 & - & 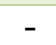 & Weaning calves early & 48 \\
\hline Fencing off grazing camps & 56 & - & - & - & r \\
\hline
\end{tabular}

Resilience strategies against climate variability

Extreme weather events such as droughts, inconsistent rains, low temperatures among others, have been witnessed frequently in the province. Farmers respond to weather variability by employing strategies that help then deal with challenges brought about by climate change.

\section{Resilience strategies for crop production}

Smallholder farmers are often characterized by farming practices that have evolved to reduce vulnerability to external shocks. Recent changes in climate have prompted farmers to employ strategies that make them resilient to climatic shocks to remain productive. Table 4 presents the resilience strategies employed by farmers in JGDM in crop production. The most common resilient strategies identified by the farmers in the district include planting short maturing variety of crops and drought-tolerant crops. $96 \%$ and $92 \%$ of the interviewed farmers mentioned using the practices respectively. Replanting after crop failure or destruction by extreme weather is another resilient strategy practiced by farmers to maintain low production and minimize risk. Farmers mentioned that due to increased frequency of droughts and dry spells, mixed cropping involving drought-tolerant crops was now common amongst the households with $83 \%$ attest in practicing the strategy. Conservation farming techniques like water harvesting to address climate change by improving soil water availability for crops is practiced by $81 \%$ of the respondents. Another drought mitigating resilience strategy that has been adopted by the farmers is planting fodder crops used to feed animals during long dry spells to ensure livestock survival. This livestock can be sold and the proceeds used to buy food and inputs for the next cropping season. Seventy two percent of the 
farmers are now committing part of their cropland to the planting of fodder. An aboveaverage number of farmers in the district practice ploughing and planting at once and delayed planting, $60 \%$ and $61 \%$ respectively, to be specific. This strategy is mainly used to ensure that the timing of planting coincides with high soil moisture content for improved germination rate. A smaller percentage had already indicated that they own irrigation equipment as implements hence only $15 \%$ of the farmers irrigated their crops frequently as a resilient strategy. The results show that $24 \%$ of the farmers employed the strategy of cleaning furrows to improve drainage. Crop resilience strategies employed by farmers ensure that these smallholder farmers remain productive in the face of climate variability. By employing these strategies farmers, ensure that they retain the same basic function after an extreme weather event.

\section{Resilience strategies for animal husbandry}

A variety of resilience strategies have been identified by farmers involved in animal husbandry (Table 4). However, the most common way amongst them is building shelter for animals to shield them against the increasing freezing winters. All the farmers involved in small and large livestock production have some sort of shelter where animals can shelter during frosty winters. Camp/Paddock rotation is another strategy practiced by all the respondents. This strategy is similar to shifting cultivation in crop production ensures that the camp recovers as the animals are rotated from one camp to the other. Sustainability is built as this ensures that there is no overgrazing on one piece of land. In addition to that, about $78 \%$ of the farmers now supply high energy licks to the animals as a feed supplement. This ensures that the animals are well fed and do not rely on the pastures only, especially during dry seasons when pastures are poor. As a supplement to suckling, calves and lambs are kept on feedlot to increase their growth rate. This practice is employed by $60 \%$ of the farmers and it ensures that calves and lambs reach their marketing stage earlier and sold at higher returns. Other resilience strategies involving supplementary feeding also include buying stock feed during droughts and storing feed from crop residue, which is practiced by $56 \%$ and $44 \%$ of the farmers, respectively.

Controlling the size of the stock is another resilient strategy used by farmers in the district. The strategy includes culling large animals like cattle (36\%) and reducing the livestock population within the farm (24\%). These strategies ensure that loses are reduced during drought as large animals and high population density tend to quickly overgraze the land resulting in animal death. An average number of farmers engage in animal management strategies, which includes vaccination/inoculation (57\%) and weaning calves and lambs early (48\%). Last but not least, $65 \%$ of the farmers have installed water tanks in the camps to ensure adequate water supply for animals.

\section{Factors affecting adaptation and resilience strategies}

Identifying strategies employed by smallholder farmers in JGDM to build resilience to climate change has remained an advantage for improving productivity. The success of these strategies is influenced by complex factors which according to de Waal and Whiteside (2003) include household demography, access to resources, the ability of the community to provide support and access to information and training. According to the results in Table 5, household size has a positive and statistically significant influence on their choices of strategies such as crop rotation, changing crops, building shelters, replanting and changing mating, calving and weaning dates. These results suggest that farm households are more inclined to adopt these strategies. These findings are consistent with traditional farm labour demand and supply dynamics. Traditionally a large family made up of adults has more hands to help with farm activities than a small family. Considering that most of the strategies influenced by household size are labour intensive, it is only households with more labour that are likely to implement these strategies.

Characteristics such as age, education and size of the family can influence a household's objectives. Age, in particular, can influence the strategies pursued by a household. In the model in Table 5, there is a positive and significant correlation between the age of a household head and the use of strategies such as building shelters, replanting and camp rotation. The results support the findings by Yesuf et al. (2008) and Anjichi (2007), who found that in Ethiopia and Kenya, older household heads were more likely to adopt climate change adaptation measures than younger farmers were. As expected, the analysis results reveal that there is a negative relationship between sex and adoption of resilience and adaptation strategies such as replanting, camp rotation and changing planting schedule. The implication being that female-headed households are less likely to engage in these strategies than male-headed households are. The results are consistent with studies in Kenya, Cote D'ivore and Burkina Faso, which highlighted that maleheaded households were likely to adopt technology such as fallowing, use of fertilizers and manure and building erosion structures (Adesina, 1996; Matlon, 1994; Njuki et al., 2008). 
Table 5. Results of pooled regression and factors influencing the adoption of a strategy for resilience and adaptation to climate change.

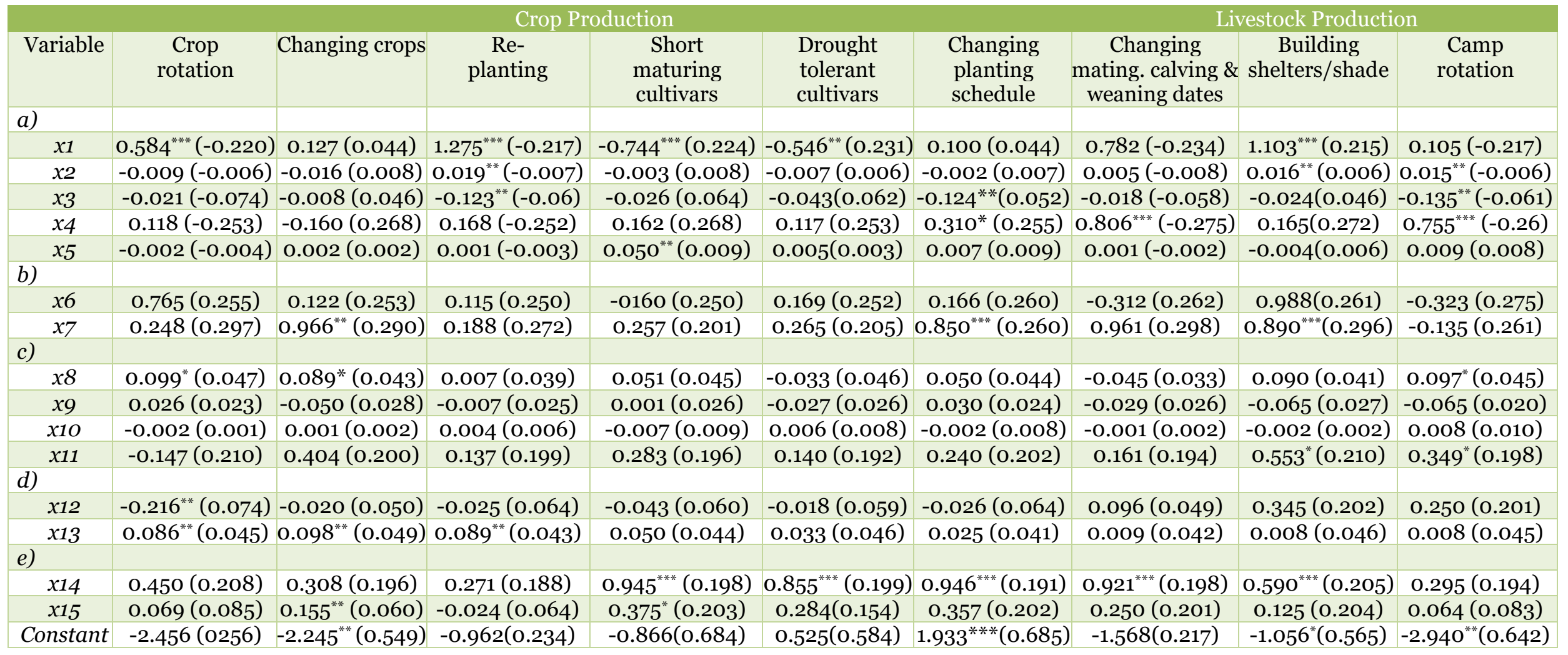

${ }^{*} P<0.10,{ }^{* *} P<0.05,{ }^{* * *} P<0.01$ and $P$ - value in parenthesis.

\section{Definition of Variables}

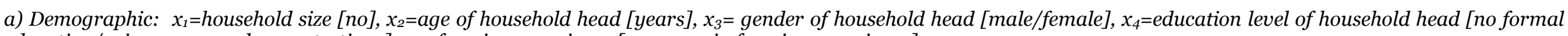
education/primary. secondary or tertiary], $x_{5}=$ farming experience [no. years in farming experience]

b) Farmers' Perceptions: $x_{6}=$ observed any weather changes in the past [no/yes]. $x_{7}=$ have heard about climate change [no/yes].

c) Assets and Resources: $x_{8}$ - land owned currently [ha]; $x_{9}=$ whether household own light implements [no/yes]. $x_{10}-$ whether household own heavy machinery [no/yes]. $x_{11}=$ whether farming is a primary occupation [no/yes].

d) Farm Activities: $x_{12}=$ whether involved in animal husbandry [no/yes]. $x_{13}=$ whether involved in crop production [no/yes].

e) Access to Information and Technology: $x_{14}=$ received training on climate change [no/yes]. $x_{15}=$ have access to weather information [no/yes]. 
According to Yesuf et al. (2008), the education of the household head has been documented as an important factor determining the adoption of technologies. An educated farmer can readily access relevant information. There is a positive and statistically significant correlation between adopting strategies such as crop rotation, changing planting schedule and changing mating, calving and weaning dates, and the education level of the household head. These results are consistent with the research findings, which revealed that $93 \%$ of the farmers had attended school at least up to the primary level and above. The farming experience of household heads seems to have little or no significant influence on the choices of resilience and adaptation strategies implemented. Farm experience has a positive and statistically significant correlation with planting a short variety of crops only. These are unexpected results because normally farmers with experience are expected to adopt technologies that counter climate change. However, it should be noted that in this survey, the average age of farm household head is 53 years and the average farm experience is 13 years. The farming experience may be taken as very little to affect many strategies.

Farmers' perceptions of climate change play an important role in the selection of particular strategies for resilience and adaptation by farmers. Results in Table 5 show a positive and statistically significant correlation between a farmer's perception and the implementation of such strategies as crop rotation, building shelters, changing planting schedules and changing crops. The implication being that farmers who perceive climate change are more likely to adopt strategies to cushion themselves against climate variability and the aftermath the changing of climate.

Regression results also show that there is a positive and statistically significant relationship between the size of land owned by a farmer and the adoption of strategies such as crop rotation, changing crops and camp rotation. The results suggest that the more the land a farmer has, the easier it is to implement such strategies that require more land to be implemented successfully. However, these results are inconsistent with the findings from a study done in Zambia, Malawi and Mozambique, which revealed that farmers cultivating more land are likely to use less amounts of fertilizer across large areas but intensify and target small areas (Njuki et al., 2008). It is also important to understand that, traditionally, strategies such as crop rotation and camp rotation require large pieces of land to be effectively practiced. Hence, those farmers with large farms are able to adopt these strategies in the district.

As expected there is a negative and statistically significant correlation between farmers involved in animal production and strategies that involve crops. Table 5 reveals that there is a negative and statistically significant correlation between animal husbandry and implementing crop rotation. In general, it is expected that farmers involved in crop production will always adopt strategies that enhance and protect crop production. Furthermore, there is a positive and statistically significant correlation between crop production and such strategies as crop rotation, replanting and changing crops. As expected, the farmers involved in crop production tend to adopt strategies that deal with improving yield and minimizing risk in particular the smallholder farmers.

There is a positive and statistically significant correlation between receiving climate change training and the implementation of strategies such as building shelters, planting short variety crops, planting drought-resistant crops, changing planting schedule as well as changing mating, calving and weaning dates. The results are consistent with the findings by Yesuf et al. (2008), which underscore the role played by formal and informal institutions in addressing the issue of climate change adaptation by farmers. A study of the Nile Basin farmers revealed that formal agricultural extension, farmer to farmer extension and access to weather information guarantees that farmers apply adaptation measures on their farms as compared to those that did not have access to training (Deressa et al., 2008). Similarly, there is a positive and statistically significant correlation between access to information and the adoption of strategies like changing crops and planting short variety of crops. These results are understandable as farmers under normal circumstances are likely to change crops or grow short maturing cultivars once they get information about looming dry conditions or unreliable rainfall patterns. In the case of JGDM, it is regrettable that there is an almost nonexistence of government, NGOs and private sector service being provided to these farmers.

\section{Conclusions}

Joe Gqabi district is currently experiencing climate change effects in the form of increasing frequency of droughts, erratic rainfalls, and increasing frosty winter days. This has affected mostly smallholder farmers' productivity by increasing yield losses, reducing the quality of their products, and increased frequency of pests and diseases, which is now threatening the future sustainability and food security of these farmers. Despite the adverse effects of climate change, farmers in the district have continued to engage in crop cultivation and animal husbandry year after year. This study has shown that farmers have remained productive due to the adoption of agricultural strategies and practices to deal with impacts of climate change and variability. The 
study has also shown that these changes in agricultural practices have been because of farmer innovation instead of external drivers.

The main strategies employed for crop production were identified as crop rotation, replanting, planting short maturing cultivars, planting drought-resistant varieties, changing planting schedule and changing crops. On the other hand, the main strategies employed in animal husbandry include building shelters for animals, changing mating, calving and weaning dates and camp/paddock rotation. Overall farmers in the district are planting fewer crops and shifting to animal production for the market. Farmers in the western municipalities like Gariep who have traditionally been involved in animal husbandry as their main farm activity are now employing a strategy of reducing large stocks in favour of small stocks like goats and sheep, which are drought tolerant. The study also showed that farmers' perceptions also influence how they build resilience and adaptation strategies. In this regard, the result showed that farmers who perceived climate change were better empowered to make rational decisions and chose the best strategies for resilience and adaptation. Strategies such as crop rotation, building shelters, changing planting schedule and changing crops were some of the strategies that were positively influenced by farmers' perceptions.

One of the key findings of this study was the lack of capacity building institutions for smallholder farmers in the district. This study recommends that public institutions like government departments and NGOs and private entities initiate participatory programs that help impart knowledge and knowhow to smallholder farmers on climate change and its impacts on agricultural systems. Pioneer farmers in the region can be identified and trained on the adoption of adaptation strategies, which they can also spread to their neighbouring farmers in prearranged peer groups. These strategies should ensure that farmers become resilient to future climate change and avoid losses in production when extreme weather events occur. The national and local governments can also help by putting in place policies that aim at strengthening those institutions dealing with smallholder farmers to increase their capacity to reach out to all farmers.

\section{Acknowledgment}

We thank for the technical assistance who helped collecting the data from Imbumba Beef Production Primary Cooperative (IBPPC), an NGO based in Ladys Grey involved in providing extension services to communal farmers. University of the Free State (UFS), whom the authors wish to express their gratitude, has supported the present work.

\section{Conflict of interest}

None of the authors has any conflicts of interest to declare.

\section{References}

Adesina, A.A. 1996. Factors affecting the adoption of fertilisers by rice farmers in Cote D'ivore. Nutr. Cycl. Agro-Ecosyst. 46: 2936. https://doi.org/10.1007/BFoo210222

Amadou, M.L., Villamor, G.B., Attua, F.M. and Traore, S.P. 2015. Comparing farmer's perception of climate change and variability with historical climate data in Upper East Region of Ghana. Ghana J. Geography. 7(1): 47-74.

Anjichi, V.E., Mauyo, L.W. and Kipsat, M.J. 2007. The Effect of Socio-Economic Factors on a Farmers' Decision to Adopt Farm Soil Conservation Measures: An Application of Multivariate Logistic Analysis in Butere/Mumias District, Kenya. In: Bationo, A., Waswa, B., Kihara, J. and Kimetu, J., (eds.) Advances in Integrated Soil Fertility Management in Sub Saharan Africa: Challenges and Opportunities. Springer, Dordrecht. pp. 915-919.

https://doi.org/10.1007/978-1-4020-5760-1_87

Berg, A., de Noblet-Ducoudre, N., Sultan, B., Lengaigne, M. and Guimberteau, M. 2013. Projections of Climate Change Impacts on potential $\mathrm{C}_{4}$ crop productivity over tropical regions. Agril. Forest Meteorol. 170: 89-102.

Boko, M., Niang, I., Nyong, A., Vogel, C., Githeko, A., Medany, M., Osman-Elasha, B., Tabo, R. and Yanda, P. 2007. Africa. In: Parry, M.L., Canziani, O.F., Palutikof, J.P., Linden, P.J. van der and Hanson, C.E. (eds.). 2007. Climate change 2007: Impacts, adaptation and vulnerability. Contribution of Working Group II to the Fourth Assessment Report of the Intergovernmental Panel on Climate Change (IPCC). Cambridge, UK: Cambridge University Press: pp. 433-467.

Burton, I. and Lim, B. 2005. Achieving adequate adaptation in agriculture. Climatic Change. Cambridge University Press. pp. 191-200. https://doi.org/10.1007/1-4020-4166-7_9

de Waal, A. and Whiteside, A. 2003. New Variant Famine: AIDS and food crisis in Southern Africa. The Lancet. 362: 1234-1237. https://doi.org/10.1016/So140-6736(03)14548-5

DLGTA. 2011. Joe Gqabi District Municipality Profile. Department of Local Governance and Traditional Affairs, Government of the Republic of South Africa.

Deressa, T., Hassan, R., Alemu, T., Yesuf, M. and Ringler. C. 2008. Analysing the determinants of farmers' choice of adaptation measures and perceptions of climate change in the Nile Basin of Ethiopia. International Food Policy Research Institute (IFPRI) Discussion Paper No. 00798. Washington, DC: IFPRI.

https://doi.org/10.1017/So021859610000687 
Deressa, T.T., Hassan, R.M. and Ringler, C. 2011. Perception of and Adaptation to Climate Change by Farmers in the Nile Basin of Ethiopia. J. Agril. Sci. 149(1): 23-31. https://doi.org/10.1017/So021859610000687

ECSECC. 2014. Annual Report. Eastern Cape Socio-Economic Consultative Council, 12 Gloucester Rd, Vincent, East London, 5217, South Africa. pp. 34-35.

FAO/OECD. 2012. Building resilience for adaptation to climate change in the agriculture sector, Red Room, Food and Agriculture Organization/ Organization for Economic Co-operation and Development (FAO/OECD). p. 88.

Gandure, S., Walker, S. and Botha, J.J. 2011. Farmers 'perceptions of adaptation to climate change and water stress in a South African rural community. Environ. Dev. 5: 39-53.

https://doi.org/10.1016/j.envdev.2012.11.004

Gbetibouo, G. 2009. Understanding Farmers' perceptions and adaptations to climate change and variability: The case of the Limpopo Basin, South Africa. Washington D.C. IFPRI Discussion Paper 00849. pp. 715 .

Ifejika, S.C. 2010. Resilient adaptation to climate change in African agriculture. Bonn: DIE. Studies/Deutsches Institut für Entwicklungspolitik. pp. 91-101.

IPCC. 2014. Climate Change 2014: Impacts, Adaptation and Vulnerability. Intergovernmental Panel on Climate Change (IPCC) WG11 AR5. Summery for Policy Makers.

https://doi.org/10.1017/CBO9781107415416

JGDM. 2015. District Integrated Development Plan. Joe Gqabi District Municipality.

Lobell, D., Banziger, M., Magorokosho, C. and Vivek, B. 2011. Nonlinear heat effects on African maize as evidenced by historical yield trials. Nature Climate Change. 1: 4245. https://doi.org/10.1038/nclimate1043

Maddison, D. 2006. The perception of and Adaptation to Climate Change in Africa. Special Series on Climate Change and Agriculture in Africa. CEEPA Discussion Paper No. 10 Discussion Paper. pp. 21-35.

Matlon, P.J. 1994. Indigenous land use systems and investments in soil fertility in Burkina Faso. In: Bruce J.W. and Migot-Adholla S.E. (eds.) Searching for Land Tenure Security in Africa. Dubuque, Iowa, USA. Kendall/Hunt Publishing Company. pp. 41-69.

Moyo, B., Masika, P.J. and Muchenje, V. 2012. Effect of supplementing Xhosa lop-eared goats castrates with Moringa oleifera leaves on growth performance, carcass and noncharacteristics. Trop. Animal Health Prod. 44: 801-809.

https://doi.org/10.1007/s11250-011-9970-6

Njuki, J. M., Mapila, M.T., Zingore, S. and Delve, R. 2008. The dynamics of social capital in influencing use of soil management options in the Chinyanja Triangle of southern Africa. Ecol. Soc. 13(2): 9-16.

https://doi.org/10.5751/ES-02539-130209
Okonya, J.S., Syndikus, K. and Kroschel, J. 2013. Farmers' perception of and coping strategies to climate change: Evidence from six agroecological zones of Uganda. J. Agril. Sci. 5(8): 252- 263 . https://doi.org/10.5539/jas.v5n8p252

Seneviratne, S.I., Nicholls, N., Easterling, D., Goodess, C. M., Kanae, S., Kossin, J., Luo, Y., Marengo, J., McInnes, K., Rahimi, M., Reichstein, M., Sorteberg, A., Vera, C. and Zhang, X. 2012. Changes in climate extremes and their impacts on the natural physical environment. In: Managing the Risks of Extreme Events and Disasters to Advance Climate Change Adaptation [Field, C.B., V. Barros, T.F. Stocker, D. Qin, D.J. Dokken, K.L. Ebi, M.D. Mastrandrea, K.J. Mach, G.-K. Plattner, S.K. Allen, M. Tignor, and P.M. Midgley (eds.)]. A Special Report of Working Groups I and II of the Intergovernmental Panel on Climate Change (IPCC). Cambridge University Press, Cambridge, UK, and New York, NY, USA. pp. 65-78.

Simelton, E., Quinn, C.H., Batisani, N., Dougill, A.J., Dyer, J.C., Fraser, E.D.G., Mkwambisi, D., Sallu, S. and Stringer, L.C. 2013. Is rainfall really changing? Farmers' perceptions, meteorological data, and policy implications. Climate Dev. 5: 123-138. https://doi.org/10.1080/17565529.2012.751893.

StatSA. 2011. Census 2011: Municipal Report. Eastern Cape. Statistics South Africa, Statistics Release, Government of South Africa.

Thompson, K., Chidawanyika, F., Kruszewska, I. and Tirado, R. 2015. Building Resilience in East African Agriculture in Response to Climate Change. Greenpeace Research Laboratories Technical Report. 05 . Greenpeace Africa.

UNFCCC. 2007. Climate Change: Impacts, Vulnerabilities and Adaptation in Developing Countries. United Nations Framework for the Convention of Climate Change (UNFCCC), Bonn. Climate Change Secretariat.

UNEP. 2015. World Urbanization Prospects: The 2014 Revision, Highlights (ST/ESA/SER.A/352), United Nations, Department of Economic and Social Affairs, Population Division, USA.

Yesuf, M., Di Falco, S., Ringler, C. and Kohlin, G. 2008. The impact of Climate Change and adaptation on Food Production in LowIncome Countries: Evidence from the Nile Basin, Ethiopia. Paper No. 15-II.

Yin, R. 2003. Case Study Research: Design and Methods. London, Sage Publications Ltd. pp. 93-95.

Ziervogel, G., New, M., van Gardern, E.A., Modgley, G., Taylor, A., Hamann, R., StuartHill, S., Myers, J. and Warburton, M. 2014. Climate change impacts and adaptation in South Africa. WIREs Climate Change. 5: 605-620. https://doi.org/10.1002/wcc.295 